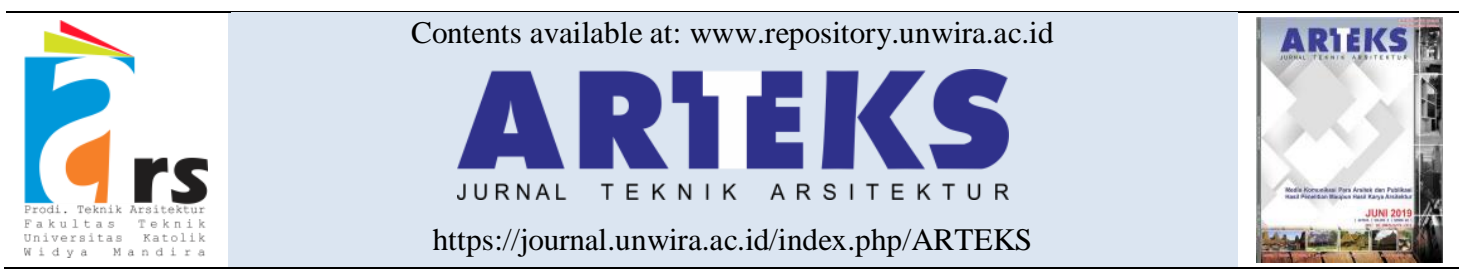

Research paper

doi: http://doi.org/10.30822/arteks.v4i1.84

\title{
Ekspresi puitik sakral pada bentuk arsitektur Gereja Protestan di Indonesia bagian Barat (GPIB) Paulus di Jakarta
}

\section{Tine Abrianti, Purnama Salura*}

Program Studi Magister Arsitektur, Fakultas Teknik, Universitas Katolik Parahyangan Jl. Merdeka no. 30, Bandung, Indonesia

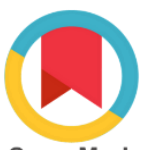

CrossMark

\begin{tabular}{l}
\hline ARTICLE INFO \\
\hline Article history: \\
Received July 18, 2019 \\
Received in revised form July 28, 2019 \\
Accepted September 25, 2019 \\
Available online December 16, 2019
\end{tabular}

ABSTRACT
Sacred poetic expression on the architectural form of Gereja
Protestan di Indonesia bagian Barat (GPIB) Paulus in Jakarta

Church architecture shows the expression of its functions in layers. The first layer can be captured in a perception through its expression indicating sacred functions. The next layer was captured

Keywords:

Church architecture

Poetic expression

Sacred expression

"Corresponding author: Purnama Salura Program Studi Magister Arsitektur, Fakultas Teknik, Universitas Katolik Parahyangan, Indonesia

Email: purnama.salura@gmail.com ORCID: https://orcid.org/0000-0002-36527192

\section{Pendahuluan}

Bentuk arsitektur Gereja terus berkembang sampai saat ini. Sebuah bangunan akan mudah dikenali fungsinya sebagai Gereja jika memiliki elemen seperti: menara yang tinggi, fasad muka yang simetris dan kaca-kaca warna di dalam ruangan yang temaram. Bangunan Gereja juga 
mudah dikenali karena memiliki kualitas kesakralan yang tidak dimiliki oleh bangunan lainnya.

Bentuk arsitektur Gereja mulai berkembang sejak lahirnya tipologi bangunan Gereja pada periode awal Masehi. Karena pengaruh sosial dan politik serta alasan keamanan, pada awalnya kegiatan ibadah Gereja dilaksanakan berpindahpindah dari rumah-rumah jemaat hingga ke kuburan bawah tanah yang disebut sebagai katakomba. Pada masa pemerintahan Kaisar Constantine secara resmi memberikan pengakuan terhadap iman Kristen, arsitektur Gereja menunjukkan perkembangan yang signifikan. Pada masa itu bangunan Gereja menggunakan bentuk Basilica, sebuah model bangunan umum yang digunakan untuk pertemuan. Arsitektur Gereja yang sangat dikenal selanjutnya berbentuk Cathedral, dan mencapai puncaknya pada bentuk Gereja dengan arsitektur Gotik (Thiry, Paul;Bennett, Richard M.; Kamphoefner 1953).

Peristiwa reformasi yang menandai terbentuknya aliran Gereja Protestan membawa perubahan dalam perkembangan arsitektur Gereja (Yusuf 2016). Perubahan bentuk arsitektur Gereja disebabkan karena adanya perbedaan konsep tentang ruang sakral yang dipahami, berkaitan dengan sifat transendensi dan imanensi Allah. Gereja Protestan pada masa itu menekankan sifat transendensi Allah yang dipahami bersifat immaterial, sehingga tidak dapat direpresentasikan kehadiran-Nya dalam ruangan yang bersifat material (Kilde 2017). Arsitektur Gereja Protestan menampilkan bentuk yang serupa dengan bangunan profan, berbeda dengan arsitektur Gereja Katolik yang berbentuk khusus, dipenuhi dengan berbagai unsur dekorasi dan patung yang merepresentasikan kehadiran Allah.

Memasuki abad ke-20, sejalan dengan berkembangnya teologi kekristenan, arsitektur Gereja Protestan menunjukkan perubahan dengan menampilkan ruang sakral dalam Gereja. Gereja Protestan mulai menggunakan bentuk-bentuk yang merepresentasikan kehadiran Allah dalam ruang sakral, namun dalam bentuk yang berbeda dengan Gereja Katolik (Kilde 2017). Perbedaan pemahaman tentang penekanan sifat transendensi dan imanensi Allah yang tercermin dalam arsitektur Gereja kemudian terjadi dalam denominasi Protestan. Munculnya gerakan Pantekosta dan Evangelical yang lebih menekankan sifat imanensi Allah, menghasilkan bentuk-bentuk Gereja yang menunjukkan ekspresi yang berbeda dan bersifat utilitarian.
Gereja-gereja ini kemudian berkembang menjadi sangat besar, dan dibangunlah bangunan Gereja yang dapat menampung ribuan jemaat yang disebut dengan istilah megachurch.

Pada saat ini, banyak bangunan Gereja, terutama yang disebut sebagai megachurch, tidak mudah dikenali fungsinya sebagai Gereja, karena bentuknya tidak berbeda dengan bangunan lain (Moroz 2016). Fenomena ini menjadi masalah seperti yang telah diungkapkan Paus Benedictus XVI dan Kardinal Antonio C. Llovera, yaitu masalah ekspresi sakral pada arsitektur Gereja (Chrisylla 2016; Trisno, Antariksa, and Salura 2016), yang ditandai oleh semakin banyaknya arsitektur Gereja yang tidak dapat dibedakan dengan bangunan profan, yang muncul secara signifikan setelah konsili Vatikan II (Farah 2009). Hal ini menunjukkan permasalahan karena arsitektur Gereja berpengaruh secara dinamis dalam kekristenan (Kilde 2011). Selain itu ruang sakral Gereja berpengaruh terhadap pemenuhan misi Gereja (McAlphine 2011). Saat ini, isu ekspresi sakral menjadi sangat penting, apalagi dengan adanya kemajuan teknologi yang dapat memungkinkan bentuk arsitektur menjadi sangat bervariasi (Torgerson 2007; Loosley 2012).

Dalam arsitektur kaitan antara ekspresi fungsi yang diakomodasi oleh bentuk arsitektur memang merupakan isu utama (Salura 2015b). Ekspresi pada bentuk arsitektur akan menampilkan makna yang ditangkap, kemudian mengalami kontekstualisasi yang selanjutnya akan kembali mempengaruhi fungsi, yang diakomodasikan dalam bentuk yang baru. Demikianlah hal ini akan terjadi terus menerus dalam suatu perputaran fungsi, bentuk dan makna (Salura and Fauzy 2012). Khususnya dalam arsitektur berfungsi religi, ekspresi bentuk bukan hanya berpengaruh terhadap aspek religius, namun juga terhadap aspek sosial dan politik (Verkaaik 2013). Dalam kaitan dengan arsitektur Gereja, ekspresi sakral menjadi sangat penting dikedepankan terutama pada Gereja Protestan. Perubahan ideologi yang berkaitan dengan ruang sakral, dimulai sejak peristiwa reformasi dan terus berkembang sampai saat ini, menjadi pemicunya (Kilde 2017).

Ekpresi sakral dalam Gereja diyakini akan muncul secara efektif apabila dapat disampaikan melalui suatu kebaruan, yaitu secara puitik. Dalam bukunya yang berjudul "The Poetic of Space", Gaston Bachelard mengungkapkan bahwa sifat puitik dapat menyentuh permukaan jiwa melalui kebaruan yang muncul dari suatu gambaran (Bachelard 1994). Ekspresi puitik juga 
dapat memberikan kepuasan intelektual, mistikal, emosional dan spiritual dalam keindahan yang intrinsik (Barbu 2010). Karena sifat-sifat inilah, maka ekspresi puitik dapat mendukung fungsi sakral Gereja. Sifat puitik yang menggugah perasaan dan membangkitkan imajinasi sangat sesuai dengan fungsi sakral Gereja sebagai sebuah ambang yang menandai perbedaan dunia profan dan sakral, untuk mengantarkan jemaat kepada Allah yang disembahnya (Barrie 2013). Beberapa Gereja yang dirancang oleh arsitek-arsitek dunia seringkali disebut sebagai karya arsitektur yang puitik, misalnya: "Notre Dame du Haut de Ronchamp" karya Le Corbusier (Kaimakliotis and Lau 2011) dan "The Church of Light" karya Tadao Ando (Baek 2014).

Dengan demikian isu ekspresi puitik sakral menjadi isu penting untuk dikedepankan dan dikaji lebih mendalam agar dapat dijadikan strategi perancangan yang melahirkan bentuk baru yang sejalan dengan kegiatan sakral Gereja. Berangkat dari uraian di atas, penelitian ini melakukan penelusuran pendekatan baru: gabungan ekspresi sakral dengan ekspresi puitik.

Penelitian ini mengedepankan alternatif cara pandang tentang ekspresi sakral pada tingkat yang tertinggi, ditampilkan secara puitik untuk membangkitkan imajinasi sakral.

Kegunaan dan manfaat yang didapat dari penelitian ini adalah: pertama, pemahaman yang mendalam tentang kaitan antara ekspresi puitik sakral dengan arsitektur Gereja. Kedua, pemahaman tentang metode penerapannya. Ketiga, pemahaman akan posisi pentingnya aspek ekspresi puitik sakral dalam perancangan Gereja yang akan datang. Keempat, pemahaman akan posisi pentingnya aspek ekspresi puitik sakral dalam konteks arsitektur Gereja secara global.

\section{Metode penelitian}

\section{Obyek studi}

Gereja Protestan di Indonesia bagian Barat disingkat GPIB Paulus didirikan pada tahun 1936 untuk mewadahi aktivitas ibadah bagi para petinggi Belanda yang tinggal di daerah Menteng. Bangunan ini merupakan fasilitas ibadah yang cukup penting pada masa itu, terlihat dari posisi tapaknya yang berada di hadapan Taman Suropati, yang terletak di pusat area Menteng. (Lihat gambar 1 b: Foto Udara Lokasi GPIB Paulus)
Sampai saat ini kondisi bangunan Gereja Paulus relatif tidak berubah dari bentuk semula ketika didirikan dan menampilkan keunikan arsitektural. Setiap hari Minggu, Gereja ini mewadahi aktivitas ibadah Kristiani yang diadakan dalam 5 kali kebaktian. Hal-hal inilah yang dijadikan dasar mengapa Gereja Paulus ditentukan sebagai objek studi penelitian.

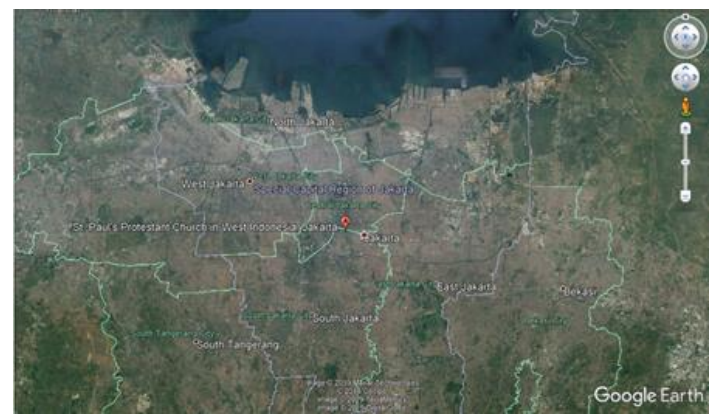

(a) Foto udara lokasi Gereja Protestan di Indonesia bagian Barat (GPIB) Paulus di area pusat DKI Jakarta

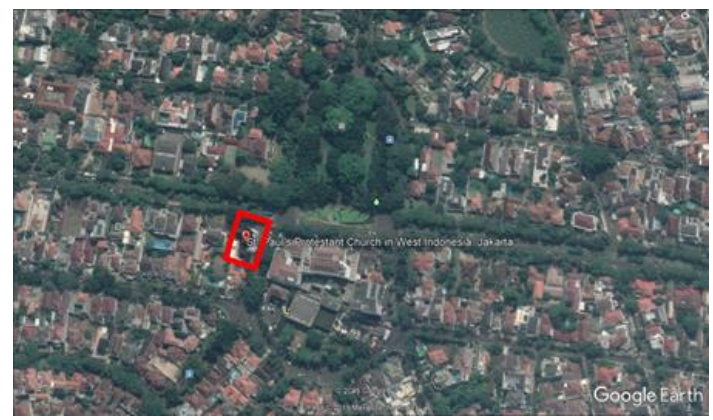

(b) Foto udara lokasi Gereja Protestan di Indonesia bagian Barat (GPIB) Paulus di Taman Suropati

Gambar 1. Peta rupa bumi (a) dan (b) lokasi Gereja Protestan di Indonesia bagian Barat (GPIB) Paulus Sumber: Dianalisis dari peta rupa bumi google earth, 2019

\section{Langkah-langkah analisis}

Pada prinsipnya analisis yang dilakukan berlandas pada teori-teori tentang arsitektur Gereja, teori tentang ekspresi arsitektural serta teori tentang bentuk dan ruang arsitektural yang dielaborasi, agar menghasilkan indikator yang dapat digunakan untuk membaca objek studi sesuai dengan konteksnya. Elaborasi teori yang dilakukan dapat dilihat dalam uraian yang berdasar langkah-langkah berikut.

Langkah pertama, elaborasi konsep sakral arsitektur Gereja Protestan ke dalam teori lapis makna (Salura 2015a). Konsep sakral arsitektur Gereja Protestan diperoleh dari penelaahan 
tentang sejarah arsitektur Gereja dan konsep tentang sakralitas Gereja yang berlandas pada konsep sakral secara umum dan konsep sakral yang tercantum dalam Alkitab.

Langkah kedua, elaborasi lapis makna ekspresi puitik sakral ke dalam konsep tentang properti dan komposisi berdasarkan teori filosofi prinsip pengaturan (Salura 2018).

Langkah ketiga, rumusan properti dan komposisi puitik sakral kemudian dielaborasi dalam setiap lingkup arsitektur, berdasarkan teori anatomi arsitektur (Salura 2018), yang terdiri dari lingkup lingkungan, lingkup tapak, lingkup bentuk bangunan, dan lingkup sosok bangunan (Salura 2010).

Berdasarkan penelusuran mendalam inilah kemudian dapat diungkap alat baca untuk menginterpretasi bentuk dan ruang arsitektur Gereja.

\section{Temuan dan pembahasan}

\section{Elaborasi konsep sakral Gereja Protestan dalam teori lapis makna}

Dalam teori lapis makna dinyatakan bahwa ekspresi yang ditampilkan pada bentuk dan ruang arsitektur dapat menyampaikan maknanya secara berlapis dan berurutan, dimulai dari makna perseptual, kemudian makna asosiatif, selanjutnya makna konvensi (simbolik), dan puitik pada lapis terakhir. Dalam penelitian ini lapis makna simbolik menjadi bagian dari lapisan makna asosiatif yang dipengaruhi oleh tradisi Gereja. Dalam tradisi Gereja, penggunaan simbol menjadi bagian yang telah disepakati secara universal, disampaikan dalam bentuk figuratif dan naratif (Barrie 2013).

Pada lapis pertama arsitektur Gereja Protestan menampilkan ekspresi sakral yang dapat ditangkap secara perseptual, menunjukkan peran ruang sakral secara umum dalam merepresentasikan Ilahi dan mengantarkan jemaat kepada yang Ilahi (Barrie 2013). Representasi Ilahi tercermin dari sifat/karakter Ilahi yang dapat ditampilkan melalui ekspresi yang terpisah, berbeda signifikan, suci, murni, misterius (Tozer 1997).

Lapis kedua menunjukkan ekspresi sakral bersifat asosiatif yang dipengaruhi tradisi Gereja dan ideologi Protestan. Tradisi Gereja menunjukkan penekanan transendensi Allah dalam ekspresi yang menampilkan ketidakterbatasan dan kemuliaan, serta penggunaan simbol figuratif seperti bentuk salib, simbol naratif yang diekspresikan dalam sekuen sakral, dan gaya Gotik/Romanesque yang telah dikenal secara universal sebagai simbol Gereja (Barrie 2013). Ideologi Protestan menunjukkan penekanan imanensi Allah, pengajaran firman dan konsep utilitarian, yang tercermin dalam ekspresi bentuk yang akrab dan minimalis (Stroik 2018).

Pada lapis yang terakhir, ekpsresi sakral Gereja Protestan mencapai tingkat yang tertinggi, ditampilkan secara puitik. Sifat puitik yang dapat menggugah emosi (emotif) dan membangkitkan imajinasi (imajinatif) melalui kebaruan (inovatif) yang ditampilkan (Bachelard 1994), sangat mendukung fungsi sakral Gereja sebagai sebuah ambang yang menandai perbedaan dunia profan dan sakral (Barrie 2013), untuk mengantarkan jemaat kepada Allah yang disembahnya.

Dalam penelitian ini ekspresi puitik yang dimaksud adalah ekspresi sakral pada tingkat yang puitik. Menurut Bachelard, filosofi puitik tidak mengenal masa lalu (Bachelard 1994). Namun dalam puitik sakral, ekspresi yang ditangkap akan terpengaruh oleh sifat-sifat sakral perseptual dan asosiatif, yang ditampilkan dalam kebaruan, sehingga menggugah perasaan dan membangkitkan imajinasi sakral.

Konsep puitik sakral arsitektur Gereja Protestan yang dielaborasi dari teori lapis makna dapat dilihat pada tabel 1.

Tabel 1. Elaborasi konsep sakral pada teori lapis makna

\begin{tabular}{|c|c|c|c|}
\hline \multicolumn{2}{|c|}{ Lapis Makna } & \multirow{2}{*}{$\begin{array}{l}\text { Deskripsi } \\
\text { Mencerminkan } \\
\text { Karakter Ilahi }\end{array}$} & \multirow[b]{2}{*}{$\begin{array}{l}\text { Ekspresi Sakral } \\
\text { Terpisah } \\
\text { Berbeda } \\
\text { Signifikan } \\
\text { Sempurna } \\
\text { Murni } \\
\text { Suci } \\
\text { Misterius }\end{array}$} \\
\hline 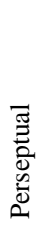 & $\begin{array}{l}\text { Fungsi } \\
\text { Sakral }\end{array}$ & & \\
\hline & & $\begin{array}{lr}\text { Mengantar kan } \\
\text { kepada Yang } \\
\text { Ilahi }\end{array}$ & Liminal \\
\hline \multirow{4}{*}{ 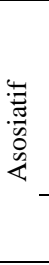 } & Tradisi & Transenden & $\begin{array}{l}\text { Tidak Terbatas } \\
\text { Mulia }\end{array}$ \\
\hline & $\begin{array}{c}\text { Gereja } \\
\text { (Katolik) }\end{array}$ & Simbolik & $\begin{array}{l}\text { Figuratif } \\
\text { Naratif } \\
\text { Gotik/ } \\
\text { Romanesque } \\
\end{array}$ \\
\hline & Ideologi & Imanen & Akrab \\
\hline & Protestan & Utilitarian & Minimalis \\
\hline & Puitik & & $\begin{array}{l}\text { Inovatif } \\
\text { Emotif } \\
\text { Imajinatif }\end{array}$ \\
\hline
\end{tabular}


Elaborasi lapis makna ekspresi sakral ke dalam konsep properti dan komposisi bentuk dan ruang arsitektur

Dalam teori filosofi prinsip pengaturan, pada tingkat konseptual, bentuk dan ruang arsitektur dapat diidentifikasi dalam 2 aspek yang selalu ada dalam arsitektur, yaitu: properti dan komposisi. Properti dapat dibedakan secara internal dan eksternal. Komposisi terdiri dari posisi dan susunan (Salura 2018). Elaborasi konsep lapis makna ekspresi puitik sakral Gereja Protestan pada properti dan komposisi arsitektur dapat dlihat pada tabel 2 .

Tabel 2. Elaborasi lapis makna ekspresi puitik sakral pada property dan komposisi arsitektur

\begin{tabular}{|c|c|c|}
\hline \multirow{2}{*}{ Ekspresi } & \multicolumn{2}{|c|}{ Properti } \\
\hline & Internal & Eksternal \\
\hline \multicolumn{3}{|l|}{ Terpisah } \\
\hline Berbeda & Spesifik/unik & Kontras \\
\hline \multicolumn{3}{|l|}{ Signifikan } \\
\hline \multicolumn{3}{|l|}{ Sempurna } \\
\hline Murni & Geometrik & \\
\hline Suci & & Putih \\
\hline \multicolumn{3}{|l|}{ Misterius } \\
\hline Liminal & $\begin{array}{c}\text { Ambang/Threshold } \\
\text { Jalur/Path }\end{array}$ & \\
\hline $\begin{array}{l}\text { Tidak } \\
\text { terbatas }\end{array}$ & $\begin{array}{c}\text { Tinggi/ } \\
\text { Besar } \\
\end{array}$ & \\
\hline Mulia & & Emas/ Berkilau \\
\hline $\begin{array}{c}\text { Simbol } \\
\text { Figuratif }\end{array}$ & Figuratif & \\
\hline \multicolumn{3}{|l|}{$\begin{array}{l}\text { Simbol } \\
\text { Naratif }\end{array}$} \\
\hline Gotik & Bentuk lancip & \\
\hline \multicolumn{3}{|l|}{ Akrab } \\
\hline Minimalis & Simple & \\
\hline Puitik & \multicolumn{2}{|c|}{$\begin{array}{c}\text { Inovatif } \\
\text { Emotif } \\
\text { Imajinatif }\end{array}$} \\
\hline \multirow{2}{*}{ Ekspresi } & \multicolumn{2}{|c|}{ Komposisi } \\
\hline & Posisi & Susunan \\
\hline Terpisah & Jauh & Berdiri sendiri \\
\hline Berbeda & & Aksen \\
\hline Signifikan & Atas & \\
\hline Sempurna & & Simetris \\
\hline Murni & & \\
\hline Suci & & \\
\hline Misterius & & Temaram \\
\hline Liminal & & $\begin{array}{c}\text { Sekuen } \\
\text { Artikulasi }\end{array}$ \\
\hline $\begin{array}{l}\text { Tidak } \\
\text { terbatas }\end{array}$ & & Vertikal \\
\hline Mulia & & \\
\hline $\begin{array}{c}\text { Simbol } \\
\text { Figuratif }\end{array}$ & & \\
\hline $\begin{array}{l}\text { Simbol } \\
\text { Naratif } \\
\end{array}$ & & Linier Fokus \\
\hline Gotik & & \\
\hline Akrab & & Memusat \\
\hline Minimalis & & Simple \\
\hline
\end{tabular}

\begin{tabular}{ccc}
\hline \multirow{2}{*}{ Ekspresi } & \multicolumn{2}{c}{ Properti } \\
\cline { 2 - 3 } & Internal & Eksternal \\
\hline \multirow{2}{*}{ Puitik } & & Inovatif \\
& & Emotif \\
& imajinatif
\end{tabular}

Elaborasi properti dan komposisi puitik sakral dalam setiap lingkup arsitektur Gereja Protestan

Identifikasi bentuk dan ruang arsitektur Gereja pada properti dan komposisi harus dilakukan dalam setiap lingkup arsitektur agar interpretasi dapat dilakukan dengan lengkap. Interpretasi ekspresi sakral arsitektur Gereja Protestan dilakukan mulai dari lingkup lingkungan, dimana properti dan komposisi tapak dan bangunan akan berpengaruh dalam menampilkan ekspresi puitik sakral. Lingkup selanjutnya meliputi indentifikasi pada massa bangunan dan aksesibilitas di dalam tapak. Memasuki bangunan, lingkup arsitektur meliputi elemen pelingkup ruang dalam yang terdiri dari lantai, dinding, dan langit-langit. Lingkup terakhir adalah identifikasi pada sosok bangunan. Pada lingkup ini hal yang penting adalah bagaimana elemen pembatas ruang berperan sebagai buffer dan filter yang mendukung fungsi bangunan dalam menampilkan ekspresi sakral. Elaborasi properti dan komposisi sakral Gereja Protestan dalam setiap lingkup arsitektur dapat dilihat pada tabel 3 .

Tabel 3. Elaborasi property dan komposisi sakral pada lingkup arsitektur

\begin{tabular}{|c|c|c|c|}
\hline \multirow{2}{*}{\multicolumn{2}{|c|}{ Indikator }} & \multicolumn{2}{|c|}{ Lingkup Lingkungan } \\
\hline & & Tapak & Bangunan \\
\hline \multirow{4}{*}{ } & \multirow{3}{*}{ Internal } & Spesifik/Unik & Spesifik \\
\hline & & & Geometri \\
\hline & & & Tinggi/Besar \\
\hline & Eksternal & Kontras & Putih \\
\hline \multirow{5}{*}{ 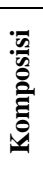 } & \multirow{2}{*}{ Posisi } & Terpisah & Terpisah \\
\hline & & Atas & Atas \\
\hline & \multirow{3}{*}{ Susunan } & Hirarki & Hirarki \\
\hline & & Batas & Simetri \\
\hline & & Aksen & Vertikal \\
\hline \multirow{2}{*}{\multicolumn{2}{|c|}{ Indikator }} & \multicolumn{2}{|c|}{ Lingkup Tapak } \\
\hline & & Bangunan & Aksesibilita \\
\hline \multirow{4}{*}{ 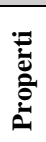 } & \multirow{3}{*}{ Internal } & Spesifik/Unik & Path/Jalur \\
\hline & & Geometri & Threshold/ \\
\hline & & Tinggi/Besar & Ambang \\
\hline & Eksternal & Kontras & Kontras \\
\hline \multirow{6}{*}{ 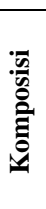 } & \multirow{2}{*}{ Posisi } & Terpisah & Terpisah \\
\hline & & Atas & Atas \\
\hline & \multirow{4}{*}{ Susunan } & Hirarki & Sekuen \\
\hline & & Simetri & Artikulasi \\
\hline & & Vertikal & Hirarki \\
\hline & & Aksen & \\
\hline \multirow{2}{*}{\multicolumn{2}{|c|}{ Indikator }} & \multicolumn{2}{|c|}{ Lingkup Bentuk Bangunan } \\
\hline & & Lantai & Dinding \\
\hline
\end{tabular}




\begin{tabular}{|c|c|c|c|}
\hline \multirow{2}{*}{\multicolumn{2}{|c|}{ Indikator }} & \multicolumn{2}{|c|}{ Lingkup Bentuk Bangunan } \\
\hline & & Lantai & Dinding \\
\hline \multirow{4}{*}{ D' } & \multirow{3}{*}{ Internal } & Spesifik & Spesifik \\
\hline & & Salib & Geometri \\
\hline & & & Tinggi/Besar \\
\hline & Eksternal & Kontras & Putih \\
\hline \multirow{6}{*}{ 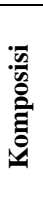 } & \multirow[b]{2}{*}{ Posisi } & Ujung & \\
\hline & & Atas & \\
\hline & \multirow[b]{4}{*}{ Susunan } & Hirarki & Hirarki \\
\hline & & Simetri & Simetri \\
\hline & & Linier Fokus & Vertikal \\
\hline & & Memusat & \\
\hline \multirow{2}{*}{\multicolumn{2}{|c|}{ Indikator }} & \multicolumn{2}{|c|}{ Lingkup Bentuk Bangunan } \\
\hline & & Langit-langit & Ornamen \\
\hline \multirow{9}{*}{ D } & \multirow{3}{*}{ Internal } & Spesifik & Spesifik \\
\hline & & Geometrik & Geometrik \\
\hline & & Salib & Tinggi/Besar \\
\hline & Eksternal & Kontras & Putih \\
\hline & \multicolumn{3}{|l|}{ Posisi } \\
\hline & \multirow{4}{*}{ Susunan } & Hirarki & Hirarki \\
\hline & & Memusat & Simetri \\
\hline & & & Linier Fokus \\
\hline & & & Memusat \\
\hline \multirow{2}{*}{\multicolumn{2}{|c|}{ Indikator }} & Lingkup S & Bangunan \\
\hline & & Elemen P & atas Ruang \\
\hline \multirow{2}{*}{ D. } & Internal & \multirow{2}{*}{\multicolumn{2}{|c|}{$\begin{array}{l}\text { Buffer } \\
\text { Filter }\end{array}$}} \\
\hline & Eksternal & & \\
\hline \multirow{2}{*}{ 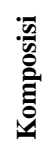 } & Posisi & \multirow{2}{*}{\multicolumn{2}{|c|}{$\begin{array}{l}\text { Buffer } \\
\text { Filter }\end{array}$}} \\
\hline & Susunan & & \\
\hline
\end{tabular}

Interpretasi properti dan komposisi sakral pada tingkat puitik juga dilakukan dalam setiap lingkup arsitektur, mulai dari lingkup lingkungan, tapak, bentuk bangunan dan sosok bangunan berdasarkan indikator properti dan komposisi puitik yang bersifat inovatif, emotif dan imajinatif.

\section{Interpretasi ekspresi puitik sakral pada arsitektur Gereja Protestan}

Dari ketiga langkah yang telah disebutkan, dapat dirumuskan sebuah alat baca untuk melakukan interprestasi ekspresi puitik sakral arsitektur Gereja Protestan, yang dilakukan dengan membaca lapis makna yang diekspresikan pada properti dan komposisi bentuk dan ruang dalam setiap lingkup arsitekturnya, seperti tercantum dalam tabel 4.
Tabel 4. Lapis makna pada property dan komposisi arsitektur Gereja Protestan

\begin{tabular}{|c|c|c|c|}
\hline \multicolumn{2}{|c|}{ Lapis Makna } & \multicolumn{2}{|c|}{$\begin{array}{c}\text { Properti \& Komposisi pada Lingkup } \\
\text { Arsitektur }\end{array}$} \\
\hline & & Lingkungan & Tapak \\
\hline \multirow{9}{*}{ 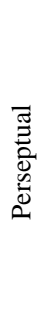 } & $\begin{array}{l}\text { Fungsi } \\
\text { khusus }\end{array}$ & $\begin{array}{l}\text { Spesifik/Unik } \\
\text { Simetris }\end{array}$ & $\begin{array}{l}\text { Spesifik/ Unik } \\
\text { Simetris }\end{array}$ \\
\hline & Fungsi & Geometrik & Geometrik \\
\hline & Sakral & Kontras & Kontras \\
\hline & & Putih & Putih \\
\hline & & Atas & Atas \\
\hline & & Aksen & Jalur/Ambang \\
\hline & & Hirarki & Hirarki \\
\hline & & Sekuen & Sekuen \\
\hline & & & Artikulasi \\
\hline \multirow{6}{*}{ 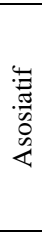 } & Tradisi & Tinggi/ Besar & Tinggi/Besar Vertikal \\
\hline & Gereja & Vertikal & Gotik/ \\
\hline & & Gotik/ & Romanesque \\
\hline & & $\begin{array}{l}\text { Romanesque } \\
\text { Salib }\end{array}$ & Salib \\
\hline & Ideologi & Memusat & Memusat \\
\hline & Protestan & Simple & Simple \\
\hline \multirow{3}{*}{\multicolumn{2}{|c|}{ Puitik }} & Inovatif & Inovatif \\
\hline & & Emotif & Emotif \\
\hline & & Imajinatif & Imajinatif \\
\hline \multirow{2}{*}{\multicolumn{2}{|c|}{ Lapis Makna }} & \multicolumn{2}{|c|}{$\begin{array}{l}\text { Properti \& Komposisi pada Lingkup } \\
\text { Arsitektur }\end{array}$} \\
\hline & & Bangunan & Sosok \\
\hline \multirow{4}{*}{ 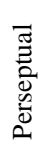 } & Fungsi & Spesifik/unik & Buffer \\
\hline & khusus & Geometrik & Buffer \\
\hline & Fungsi & Putih & \\
\hline & Sakral & Hirarki & \\
\hline \multirow{9}{*}{ 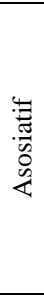 } & Tradisi & Tinggi/Besar & Buffer \\
\hline & Gereja & Vertikal & Filter \\
\hline & & Gotik/ & \\
\hline & & Romanesque & \\
\hline & & Salib & \\
\hline & & Emas/Berkilau & \\
\hline & & Linier fokus & \\
\hline & Ideologi & Memusat & Buffer \\
\hline & Protestan & Simple & \\
\hline \multirow{3}{*}{\multicolumn{2}{|c|}{ Puitik }} & Inovatif & Inovatif \\
\hline & & Emotif & Emotif \\
\hline & & Imajinatif & Imajinatif \\
\hline
\end{tabular}

\section{Ekspresi puitik sakral pada arsitektur Gereja Paulus}

Berdasarkan analisis yang dilakukan dengan menggunakan alat baca yang telah dirumuskan dari hasil elaborasi properti dan komposisi puitik sakral dalam setiap lingkup arsitektur, maka lapis ekspresi sakral yang ditampilkan Gereja Paulus dapat diuraikan dalam penjelasan berikut ini.

Pada lingkup lingkungan arsitektur Gereja Paulus menampilkan ekspresi sakral pada tingkat yang puitik. Posisi tapak Gereja ini berada di hadapan Taman Suropati, yang terletak di pusat area Menteng. Ruang terbuka di hadapan Taman Suropati memberi jarak pandang yang cukup, 
sehingga bangunan dapat tampil secara utuh dari arah taman.

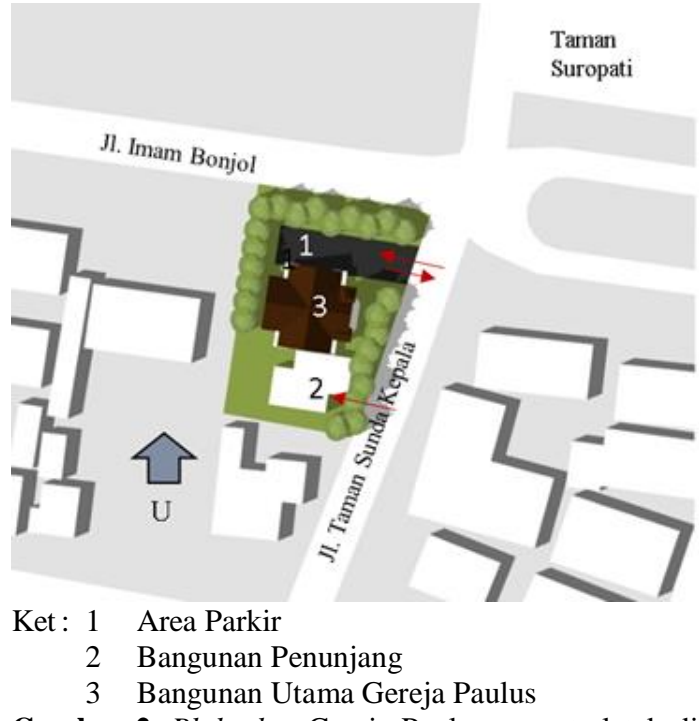

Gambar 2. Blok plan Gereja Paulus yang terletak di hadapan Taman Suropati

Ekspresi sakral dari bentuk bangunan Gereja Paulus dapat tampil secara puitik karena ruang terbuka di depan Taman Suropati memberi jarak pandang yang cukup ke arah bangunan Gereja. Proporsi atap dengan kemiringan yang tajam mendominasi massa bangunan yang berbentuk salib. Menara yang menjulang memperkuat kesan vertikal. Komposisi atap dan menara memberi gambaran tentang suatu tempat yang tinggi, membangkitkan imajinasi sakral tentang kediaman Allah. Tatanan bentang alam pada Taman Suropati membuat bangunan tampil secara kontras. Bentuk geometrik atap yang lugas muncul di antara lingkungan yang natural, berpadu menampilkan ekspresi puitik sakral.

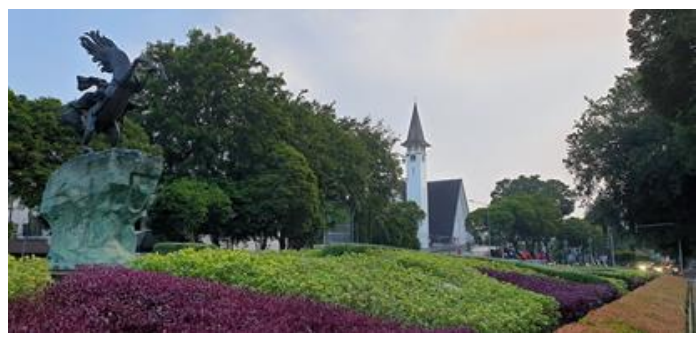

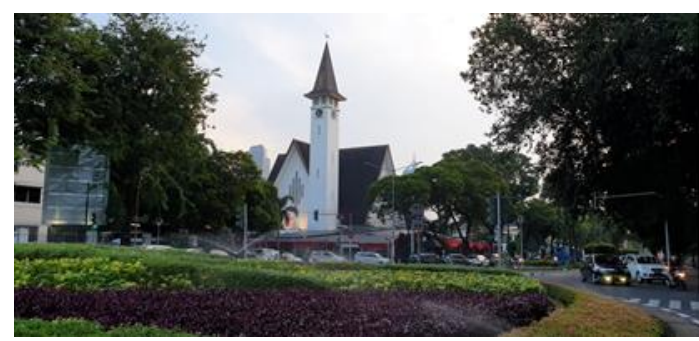

Gambar 3. Ekspresi puitik sakral pada arsitektur Gereja Paulus yang ditangkap dalam lingkup lingkungan

Memasuki tapak, menara putih yang tinggi menjulang dan atap dengan kemiringan yang tajam masih dapat ditangkap pada jarak tertentu, memberi kesan vertikal yang menunjukkan transendensi Allah, pengaruh tradisi Gereja. Tampilan bangunan yang simple menunjukkan pengaruh ideologi Protestan yang utilitarian (lihat gambar 4).
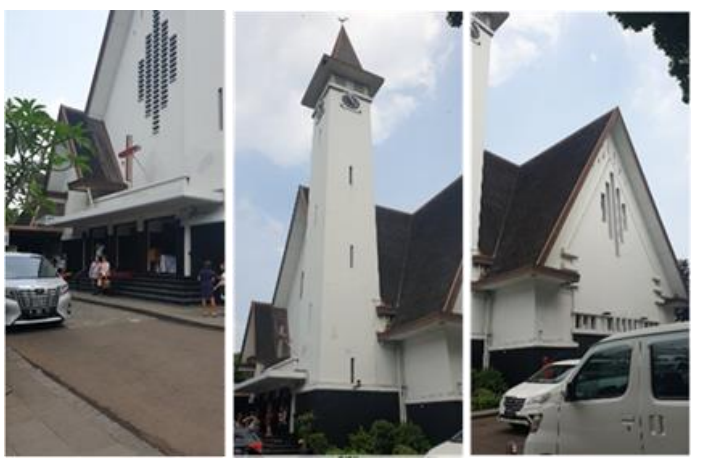

Gambar 4. Ekspresi sakral Gereja Protestan Paulus yang ditangkap dalam lingkup tapak

Tangga entrance ke dalam bangunan setinggi 5 tanjakan anak tangga menunjukkan hirarki bangunan. Tangga ini juga menjadi artikulasi dalam sekuen spasial yang mengantarkan jemaat mencapai tujuan utama di dalam ruang ibadah (lihat gambar 5).

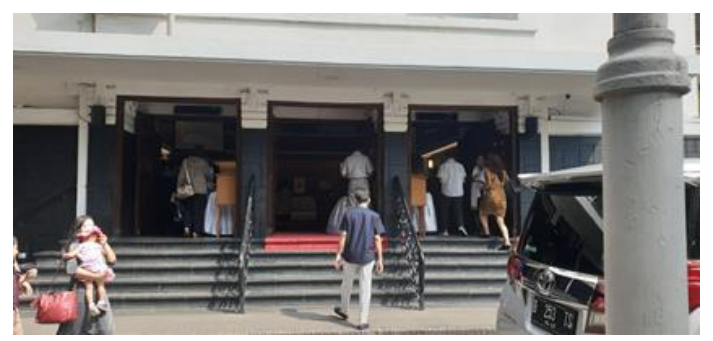

Gambar 5. Tangga entrance menuju bangunan menjadi artikulasi dalam sekuen spasial dalam tapak 
Dalam lingkup bentuk bangunan yang ditangkap ketika memasuki Gereja, pengaruh tradisi Gereja dan ideologi Protestan semakin kuat ditampilkan dalam ruang ibadah. Denah bangunan berbentuk salib, yang merupakan simbol utama kekristenan. Konsep memusat dari ideologi Protestan menghasilkan bentuk salib sama sisi yang simetris. (Lihat gambar 6 dan gambar 7)

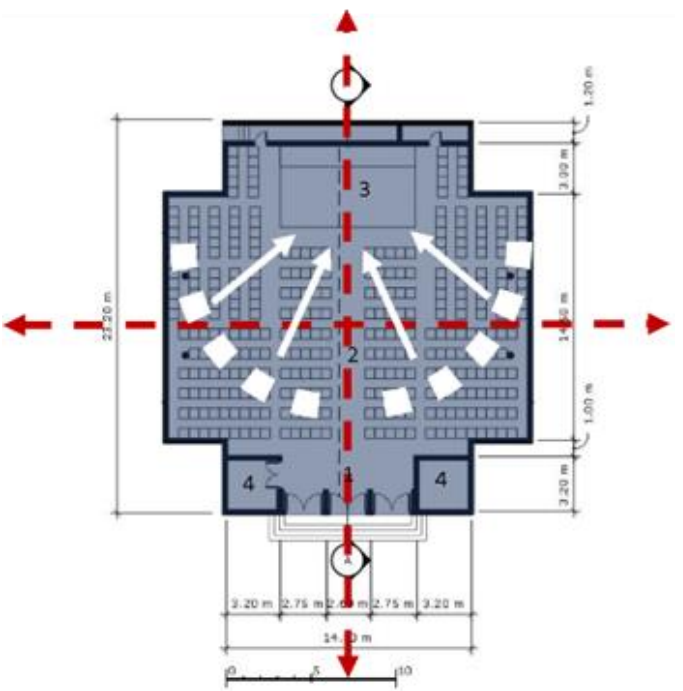

Gambar 6. Denah lantai dasar Gereja Protestan Paulus

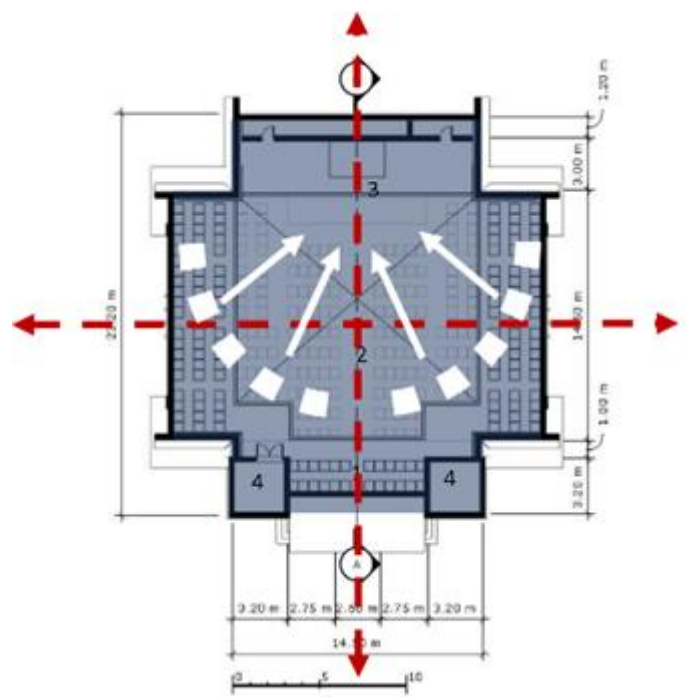

Gambar 7. Denah lantai atas Gereja Protestan Paulus

Susunan kursi jemaat merupakan gabungan sistem linier fokus dan memusat. Susunan ini menunjukkan pengaruh tradisi Gereja yang mengarahkan jemaat untuk berorientasi ke area altar dan mimbar yang menempati hirarki tertinggi. (Lihat gambar 8) Ideologi Protestan menekankan pentingnya penyampaian firman yang merata bagi seluruh jemaat, dan mengekspresikan sifat imanensi Allah yang hadir di tengah umat-Nya. (Lihat gambar 9)

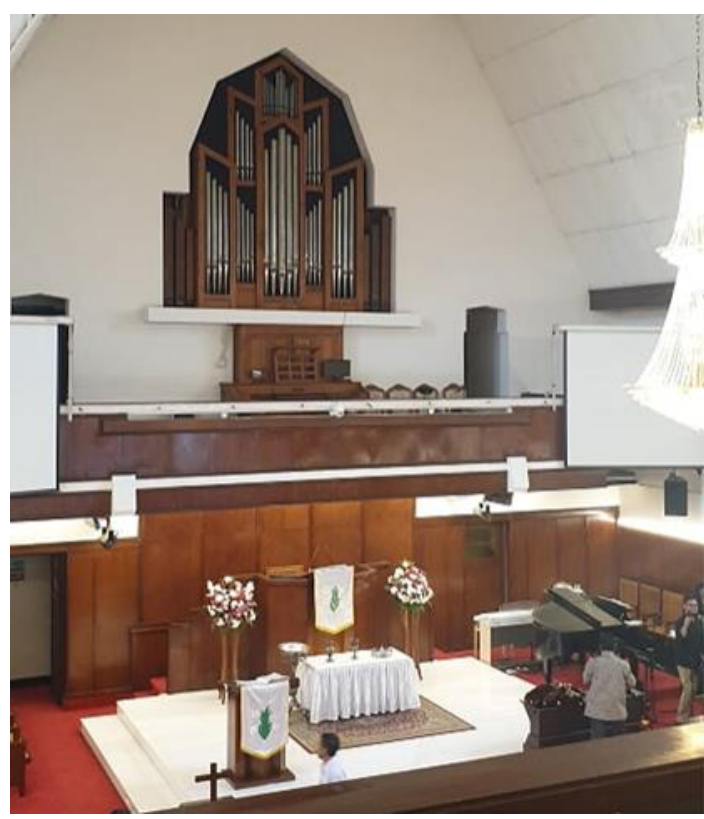

Gambar 8. Interior Gereja Protestan Paulus menunjukkan hirarki altar dan mimbar, sebagai pusat orientasi jemaat dalam ruang ibadah

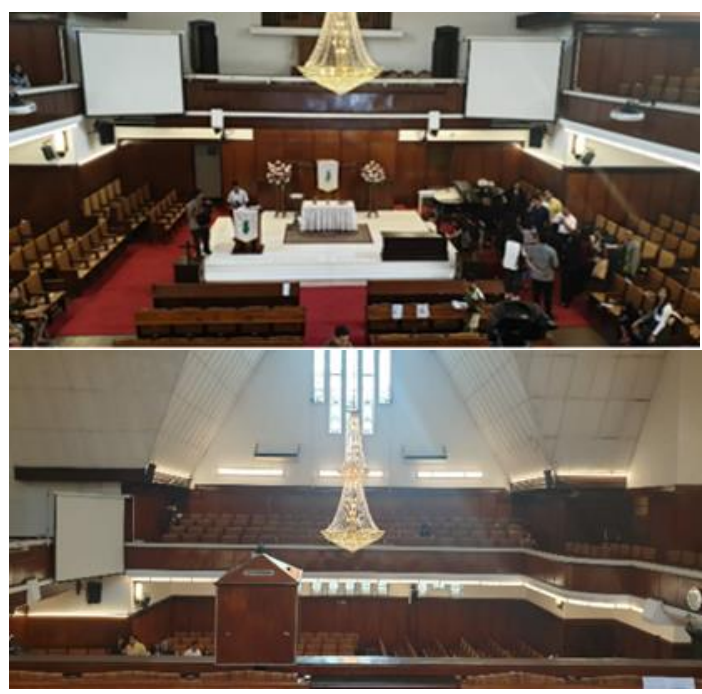

Gambar 9. Interior Gereja Protestan Paulus menunjukkan kursi jermaat yang saling berhadapan, membentuk susunan memusat namun tetap berorientasi ke altar dan mimbar

Dinding sebagai salah satu pelingkup ruang dalam di Gereja Paulus menampilkan kesan 
vertikal dari bentuknya yang mengikuti kemiringan atap yang tajam, menciptakan ruang dalam bangunan yang menjulang ke atas. (Lihat gambar 9) Kesan vertikal menunjukkan sifat Allah yang transenden.

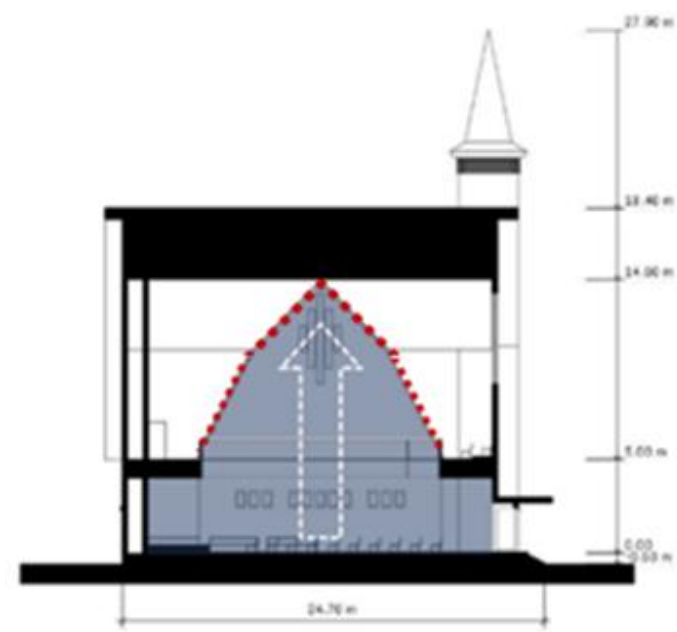

Gambar 10. Potongan bangunan Gereja Protestan Paulus menunjukkan bentuk langit-langit yang memberi kesan vertikal di dalam ruang ibadah

Material dinding pada bagian bawah bangunan didominasi kayu berwarna coklat yang kontras dengan warna putih di bagian atas dinding. Warna coklat memperkuat warna putih dalam menampilkan ekspresi kesucian di dalam ruang ibadah. (Lihat gambar 8 dan gambar 9)

Langit- langit pada ruang ibadah Gereja Paulus mencerminkan bentuk atap, yang berbentuk salib sama sisi mengikuti bentuk denah. Bentuk salib pada langit-langit dipertegas oleh list kayu berwarna coklat yang kontras dengan warna material langit-langit yang berwarna putih.

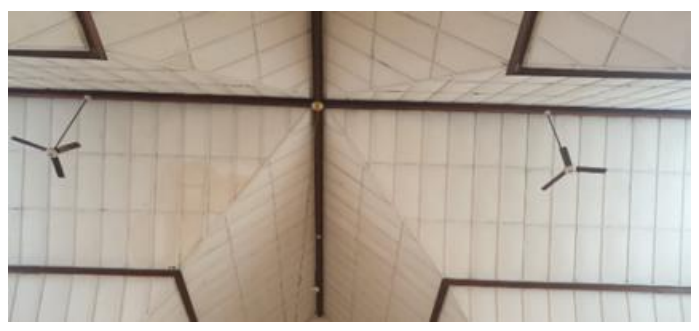

Gambar 11. Langit-langit dalam ruang Gereja Protestan Paulus mencerminkan atap berbentuk salib sama sisi

Ornamen dalam Gereja Paulus berupa alat musik orgel berukuran besar, berbentuk simetris, berwarna kontras dengan dinding putih. Ornamen lainnya adalah lampu gantung kristal yang cukup besar, bersinar emas. Posisi orgel di atas mimbar, memperkuat hirarki mimbar. Posisi lampu kristal yang digantung tepat di tengah ruang kebaktian menandai orientasi ruang yang memusat.

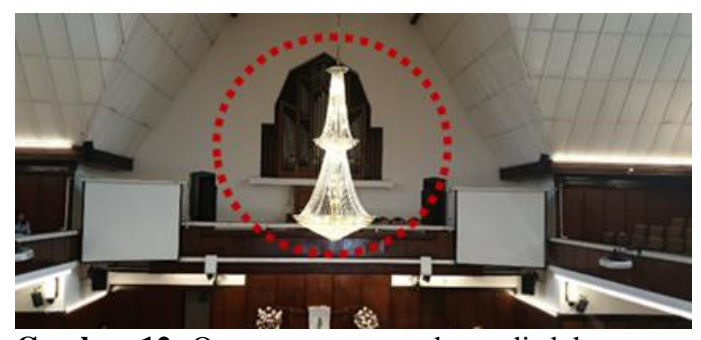

Gambar 12. Ornamen yang terdapat di dalam ruang Gereja Protestan Paulus bersifat fungsional, yakni berupa alat musik orgel dan lampu gantung kristal

Dalam lingkup sosok bangunan, pengaturan keterbukaan pada dinding Gereja Paulus juga menunjukkan pengaruh tradisi Gereja dan ideologi Protestan. Pada bagian bawah bangunan elemen pembatas ruang berfungsi sebagai buffer yang menjaga konsentrasi jemaat dari pengaruh ruang luar. Bukaan pada bagian bawah bangunan hanya berupa jendela-jendela kecil dengan material kaca patri. (Lihat gambar 13) Bukaan pada dinding gable di bagian atas bangunan menjadi filter bagi sinar matahari. Pada sisi Barat dan Timur bukaan berupa celah-celah tipis yang disusun membentuk garis vertikal. Pada sisi Utara dan Selatan bukaan menggunakan kaca patri. Cahaya yang masuk menampilkan keindahan warna kaca patri. (Lihat gambar 14)

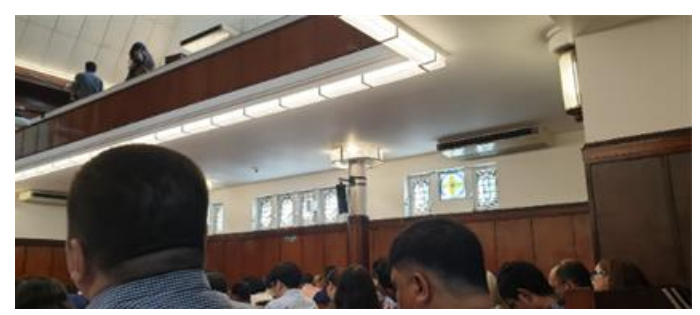

Gambar 13. Bukaan pada bagian bawah ruang ibadah Gereja Protestan Paulus, berupa jendela kaca patri berukuran kecil 


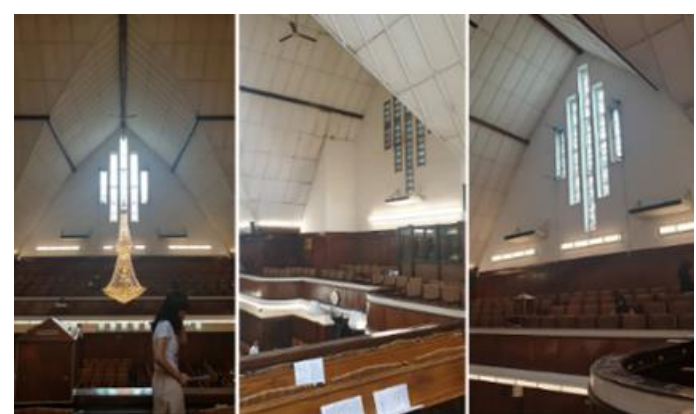

Gambar 14. Bukaan pada bagian atas ruang ibadah Gereja Protestan Paulus

Lapis makna yang ditampilkan pada arsitektur Gereja Protestan Paulus dapat dilihat dalam tabel 5 berikut ini:

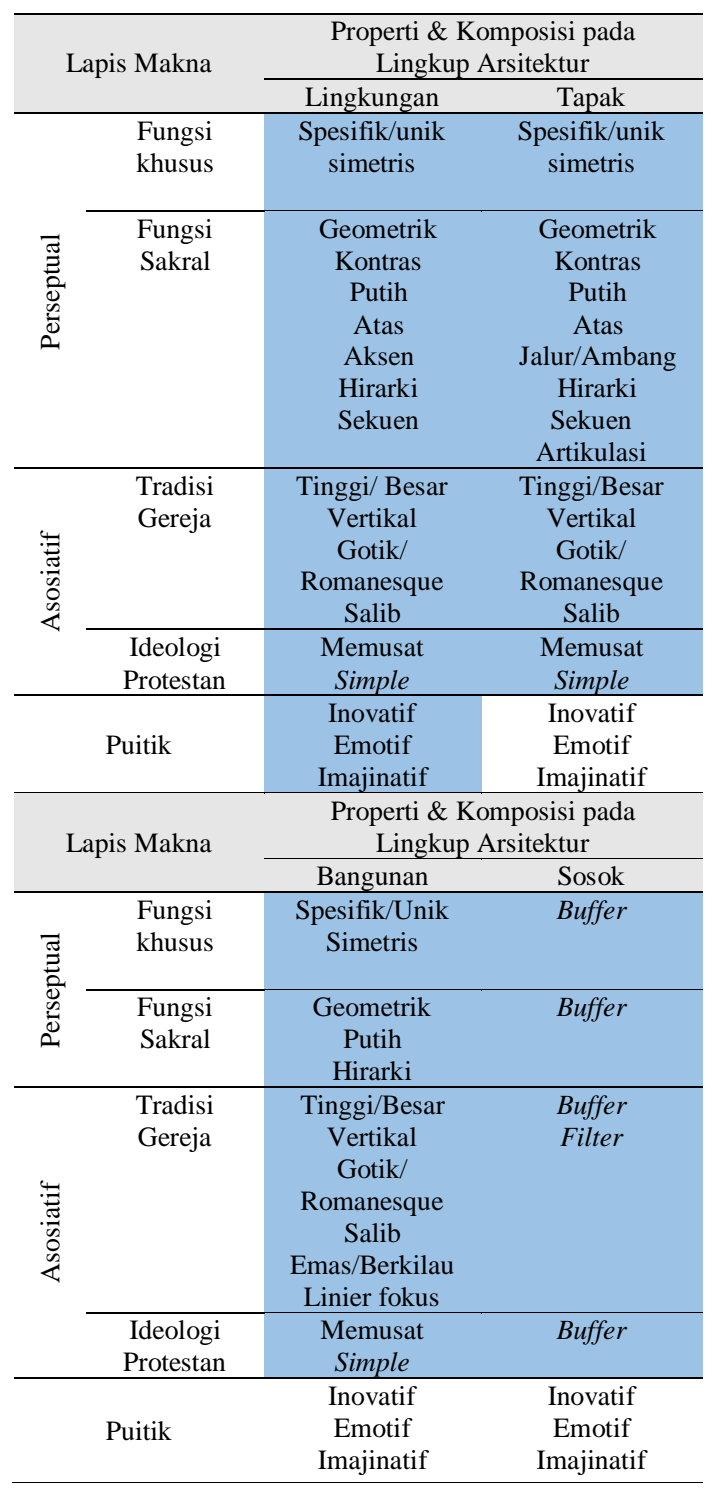

\section{Kesimpulan}

Berdasar hasil analisis dapat disimpulkan bahwa:

Pertama, kaitan antara ekspresi sakral puitik dengan bentuk arsitektur Gereja GPIB adalah sebagai berikut. Dalam lingkup lingkungan arsitektur Gereja Paulus menampilkan ekspresi sakral pada tingkat yang puitik dari properti dan komposisi massa bangunan yang membangkitkan imajinasi spiritual, tampil kontras dengan bentang alam di hadapannya. Dominasi atap pada massa bangunan berbentuk salib dengan kemiringan yang tajam, diperkuat dengan menara yang menjulang membangkitkan imajinasi tentang tempat kediaman Allah di tempat yang tinggi. Pada lingkup tapak, lingkup bentuk dan lingkup sosok bangunan, arsitektur Gereja Paulus menampilkan ekspresi sakral yang dipengaruhi tradisi Gereja dan ideologi Protestan. Tradisi Gereja ditampilkan dari bentuk yang mengarah ke atas, memberi kesan vertikal. Ideologi Protestan diekspresikan pada susunan yang cenderung memusat dan tampilan bentuk yang simple.

Kedua, ekspresi puitik sakral dapat diperoleh dengan cara menampilkan suatu kebaruan dalam ekspresi sakral yang ditangkap secara perseptual dan asosiatif.

Ketiga, pemahaman akan ekspresi puitik sakral sangat penting dalam perancangan Gereja karena sifat puitik yang dapat menggugah perasaan dan membangkitkan imajinasi sangat mendukung fungsi sakral Gereja dalam mengantarkan jemaat menuju perjumpaan spiritual dengan Allah.

Keempat, dalam kondisi global yang relatif selalu berubah-ubah, penelitian ini akan menjadi titik berangkat bagi peneltian lain.

\section{Referensi}

Bachelard, Gaston. 1994. Poetics of Space. The Unitarian Universalist Association of Congregations. Boston: Beacon Press.

Baek, Jin. 2014. Nothingness: Tadao Ando's Christian Sacred Space. Nothingness: Tadao Ando's Christian Sacred Space. https://doi.org/10.4324/9780203642818.

Barbu, Maria. 2010. 'About Poetics of Architecture'.

Barrie, Thomas. 2013. The Sacred In-between: The Mediating Roles of Architecture. The Sacred In-Between: The Mediating Roles of 
Architecture.

https://doi.org/10.4324/9781315881119.

Chrisylla, Meielisa. 2016a. 'Architectural Design Symbolism Catholic Church of Saint Peter and The Virgin Mary Catholic Church'. ARTEKS Jurnal Teknik Arsitektur.

. 2016b. 'Simbolisasi Pada Rancangan Arsitektur Gereja Katolik Santo Petrus Dan Gereja Katolik Santa Perawan Maria Tujuh Kedukaan Di Kota Bandung'. ARTEKS: Jurnal Teknik Arsitektur 1 (1): 1-14. https://doi.org/10.30822/artkeks.v1i1.20.

Farah, Jenna Victoria. 2009. 'The Implication of The Second Vativan Council of Historic American Chatolic Architecture'.

Kaimakliotis, Dimitris, and Benson Lau. 2011. 'The Poetics of Contemplative Light in the Church of Notre-Dame-Du-Haut Designed by Le Corbusier'. In PLEA 2011 - Architecture and Sustainable Development, Conference Proceedings of the 27th International Conference on Passive and Low Energy Architecture.

Kilde, Jeanne Halgren. 2011. Sacred Power, Sacred Space: An Introduction to Christian Architecture and Worship. Sacred Power, Sacred Space: An Introduction to Christian Architecture and Worship. https://doi.org/10.1093/acprof:oso/97801953 14694.001.0001.

. 2017. 'Protestant Theologies and the Problem of Sacred Space'. Actas de Arquitectura Religiosa Contemporánea 5: 223.

https://doi.org/10.17979/aarc.2017.5.0.5140.

Loosley, Emma. 2012. The Architecture and Liturgy of the Bema in Fourth- to SixthCentury Syrian Churches. Edited by Emma Loosley. 1st ed. Netherlands: Koninklijke Brill NV, Leiden, The Netherlands. Koninklijke Brill NV incorporates the imprints Brill, Global Oriental, Hotei Publishing, IDC Publishers and Martinus Nijhoff Publishers.

McAlphine, William R. 2011. SACRED SPACE for the Missional Church. Eugene: Wipf \& Stock an imprint of Wipf and Stock publishers.

Moroz, Sarah. 2016. 'Megachurchs,
Photographing America's Drab New Chatedrals'. The Guardian. 2016.

Salura, Purnama. 2010. Arsitektur Yang Membodohkan. 1st ed. Bandung: CSS Publishing.

_. 2015a. 'Rethinking Architectural Design Studio Education in Global Era'. International Journal of Academic Research 7 (3): 218-21.

- 2015b. Sebuah Kritik: Arsitektur Yang Membodohkan. Bandung: Gakushudo Publisher.

. 2018. 'The Philosophy of Architectural Ordering Principles'. International Journal of Engineering and Technology(UAE) 7 (2.9): 52-55.

Salura, Purnama, and Bachtiar Fauzy. 2012. 'The Ever-Rotating Aspects of Function-FormMeaning in Architecture'. International Journal of Basic and Applied Scientific Research.

Stroik, Duncan. 2018. 'Nova Contrareformatio'. The Institute of Sacred Architecture, 2018.

Thiry, Paul;Bennett, Richard M.; Kamphoefner, Henry L. 1953. Churches \& Temples. New York: Reinhold Publisher Corporation.

Torgerson, Mark A. 2007. An Architecture of Immanence Architecture for Worship and Ministry Today. Grand Rapids, Michigan: WM.B. Eerdemans Publishing Co.

Tozer, A.W. 1997. The Attribute of God Volume 1.

Trisno, Rudy, Antariksa Antariksa, and Purnama Salura. 2016. 'PENGARUH FUNGSI RITUAL PADA BENTUK ARSITEKTUR Kasus Studi: Gereja Katedral, Gereja Theresia,Gereja Salib Suci, Gereja Santo Matias Rasul Dan Gereja Stella Maris'. NALARs. https://doi.org/10.24853/nalars.15.1.25-34.

Verkaaik, Oscar, ed. 2013. Religious Architecture Anthropological Perspectives. Amsterdam: Amsterdam University Press.

Yusuf, Stephanie Arvina. 2016. 'Wujud Akulturasi Arsitektur Pada Aspek Fungsi, Bentuk, Dan Makna Bangunan Gereja Kristen Pniel Blimbingsari Di Bali'. ARTEKS : Jurnal Teknik ArsitekturJurnal Teknik Arsitektur 1 (2): 15-30. https://doi.org/10.30822/arteks.v1i1.22. 
ARTEKS : Jurnal Teknik Arsitektur, Volume. 4, Issue 1, December 2019 eISSN 2541-1217; pSSN 2541-0598 